\title{
Morphology and microstructure of microbiotic soil crusts on a tiger bush sequence (Niger, Sahel)
}

\author{
O. Malam Issa ${ }^{a}{ }^{*}$, J. Trichet $^{a}$, C. Défarge ${ }^{a}, A$. Couté $^{b}$ and C. Valentin ${ }^{c}$ \\ ${ }^{a}$ Institut des Sciences de la Terre d'Orléans, C.N.R.S.-Université d'Orléans, B.P. 6759, 45067 \\ Orleans cedex 2, France \\ ${ }^{\mathrm{b}}$ Muséum National d'Histoire Naturelle, Laboratoire de Cryptogamie, 12, rue Buffon, 75005 \\ Paris, France \\ ${ }^{c}$ ORSTOM, RED, 209-213, rue La Fayette, 75480 Paris, France
}

\section{Abstract}

Microbiotic crusts resulting from the colonization of soil surfaces by communities of microorganisms dominated by cyanobacteria, eucaryotic algae or lichens are widespread in arid and semi-arid regions. In the 'tiger bush' of Niger (Sahel) microbiotic crusts occur in bare bands between densely vegetated bands. The tiger bush soils are sandy loams with $\mathrm{pH}$ 4.7-6.5. Three different microbiotic crusts are recognised, forming strips parallel to the vegetation banding. They are all formed mainly by filamentous cyanobacteria dominated by Schizothrix. Other important genera are Scytonema, Lyngbya, Microcoleus, Nostoc and Phormidium. The filamentous micro-organisms trap sand particles and finer particles stick on the filament surfaces. These effects enhance soil cohesion and resistance to erosion. Soil porosity is also increased by the microbial cover, with additional pores delineated by filaments on the surfaces of crusts and porous organic bodies derived from microbial remains at depth. The microbiotic crusts are essential components of the tiger bush ecosystem. Water leaving the lower sides of vegetated bands results in plant decay, and on the upslope sides vegetation grows because of increased water supply. Microbial covers help resist erosion, and increase water and nutrient retention, thus providing substrates for the expansion of plants from adjacent vegetated bands.

Author Keywords: Cyanobacteria; Microbiotic crusts; Sahel; Soil micromorphology; Soil stabilisation; Tiger bush

\section{Introduction}

Biological and physical crusts are the main types of soil crust in arid and semi-arid regions. Physical crusts are formed by the action of water and, to a lesser extent, wind on soil particles at the surface of bare areas. Biological crusts, also called microbiotic crusts, result from the development of communities of micro-organisms (comprising generally cyanobacteria, eucaryotic algae, and lichens, but also bacteria, mosses, liverworts or fungi) on the surface of physical crusts.

Microbiotic crusts occur in arid and semi-arid regions of USA (Rychert and Skujins, 1974; Klubek and Skujins, 1980; Cole, 1990; Beymer and Klopatek, 1991; Belnap and Gardner, 1993), in steppe environments of Australia (Eldridge, 1993a and Eldridge, 1993b), China (Reynaud and Lumpkin, 1988), in Israel (Verrecchia et al., 1995), and Sahelian Africa (Barbey and Couté, 1976; Dulieu et al., 1977; Isichei, 1980). They play major roles in soil 
stabilisation against both water and wind erosion (Campbell et al., 1989; Belnap and Gardner, 1993), and in water infiltration and generation of runoff (Eldridge and Greene, 1994). Loope and Gifford (1972) report that microbiotic crusts enhance water infiltration and prevent runoff, whereas Brotherson and Rushforth (1983) and Verrecchia et al. (1995) suggest the opposite. Microbiotic crusts also enhance moisture content (Belnap and Gardner, 1993; Verrecchia et al., 1995) and increase available nutrients by concentrating essential elements, such as nitrogen, which is fixed by cyanobacteria (Harper and Pendleton, 1993).

Microbiotic soil crusts commonly occur in association with physical soil crusts, which can be divided into three main groups on the basis of their mechanisms of formation: (i) structural crusts (Fig. 1), formed in situ by water drop impact; (ii) depositional crusts (Fig. 1), formed by deposition of particles transported by water from their original location; and (iii) erosion crusts (Fig. 1), formed by water or wind erosion of the two former crusts.

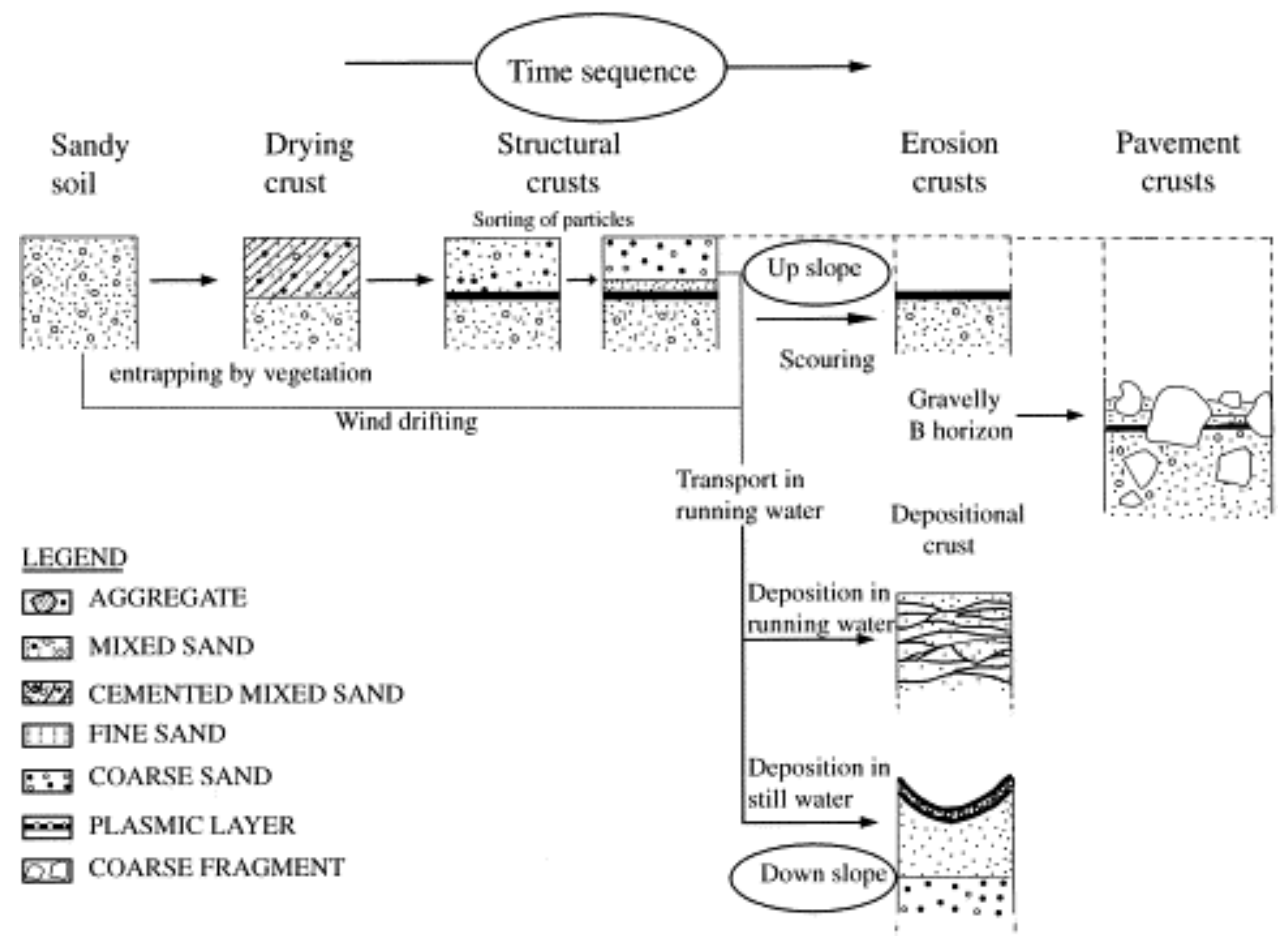

Fig. 1. Diagrammatic representation of the time sequence of soil crust formation (modified from Bresson and Valentin, 1990).

In the Sahelian zone of Niger, physical crusts comprise mainly sieving crusts, runoff crusts, still water depositional crusts and erosion crusts. Sieving crusts are structural crusts formed from two or three layers of sorted material (Fig. 1). The two-layered type is composed of a superficial layer of loose, coarse to medium sand overlying a plasmic (silt and clay) layer. The three-layered type comprises a top layer of loose coarse sand, a middle layer of fine sand, and a thin plasmic bottom layer. Pavement crusts (Fig. 1) are sieving crusts containing pebbles and gravels. Runoff crusts (Fig. 1) are very compact depositional crusts formed by deposition of particles transported by water. They exhibit submillimetric micro-layers, which are alternately coarse and fine. Still water depositional crusts (Fig. 1), also named sedimentation crusts, are formed by the deposition of particles in still water. They consist of densely packed and well-sorted particles, the size of which gradually increases with depth. The superficial 
layer is usually clay-rich and breaks into curled-up plates during periods of desiccation. Erosion crusts (Fig. 1) consist of a thin, smooth, clay-rich surface layer left after erosion of an overlying sand layer.

In this paper, we report detailed micromorphological observations on microbiotic crusts in the 'tiger bush' landscape near the village of Banizoumbou, in western Niger, in the Sahelian region of west Africa. The roles of these crusts in soil stabilisation and the water regime of the Sahelian environment are discussed.

\section{Site descriptions, materials and methods}

\subsection{Site descriptions}

Banizoumbou is about $70 \mathrm{~km}$ north-east of Niamey, the capital city of Niger. The study site lies between $13^{\circ} 32^{\prime} \mathrm{N}$ and $2^{\circ} 42^{\prime \prime} \mathrm{E}$, on a plateau formed by Tertiary fluvio-lacustrine deposits ('Continental terminal'; Greigert, 1966). The plateau, which is dissected in several parts by erosion, exhibits a slight slope of a maximum of 1\% (Ambouta, 1997). A thick ferruginous duricrust caps the summit of the plateau (Fig. 2a), and underlies a 35-60 cm thick soil.

The climate is typical of the southern Sahel, with an annual rainfall of about $560 \mathrm{~mm}$, occurring from mid-May to mid-September. Mean minimum and maximum temperatures are $22^{\circ}$ and $34^{\circ} \mathrm{C}$, respectively.

The vegetation of the plateau shows a characteristic pattern consisting of alternating densely vegetated bands comprising small trees and shrubs (Fig. 2a, arrows) and bare soil bands. From the air the resulting landscape resembles a tiger's fur (Fig. 2a), and is called 'tiger bush'. Examination of the vegetation banding reveals two distinct regions in each band (Fig. 3): a decaying section on the lower side, and a flourishing part on its upper side. This pattern is thought to be controlled by the downward movement of water (Ambouta, 1984; Cornet et al., 1992). The lower side of a band loses water, which is trapped by the upper section of the adjacent downslope band. This results in a gradual movement of the vegetated bands in an upslope direction at a rate of about $25 \mathrm{~cm} \mathrm{yr}^{-1}$ (Thiéry et al., 1995; d'Herbès et al., 1997). 

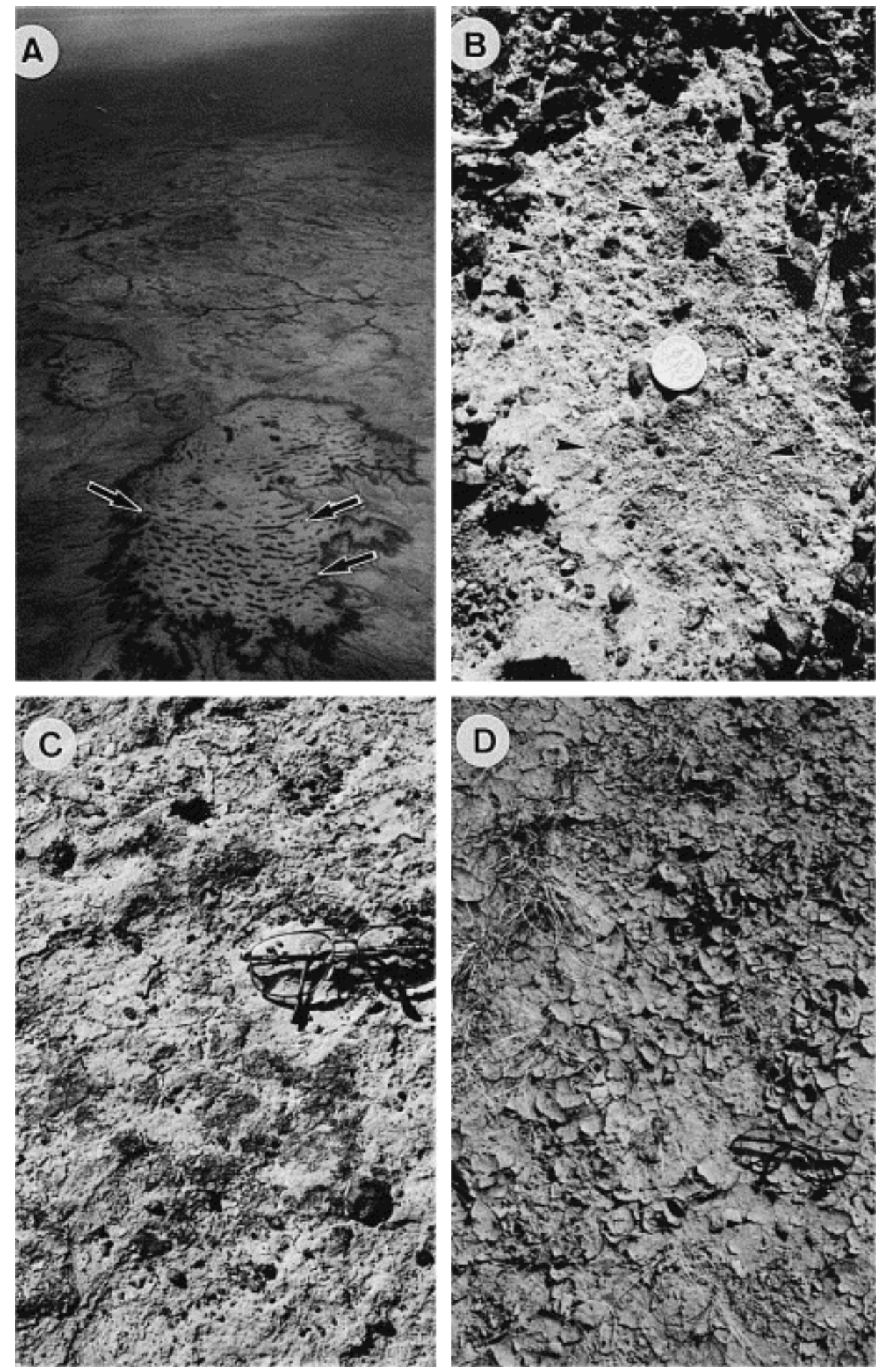

Fig. 2. Views of the sites studied. (a) Aerial view of the tiger bush landscape in western Niger on the top of a dissected plateau. Note the subparallel vegetation bands (arrowed), and the dark section of the ferruginous duricrust at the top of the cliff, approximately $15-20 \mathrm{~m}$ high, delimiting part of the plateau. (b-f) Views of the soil surface in the sites studied. (b) Site 1: The coarse superficial material was swept away to show the underlying fine sand layer, and vesicular pores (arrowed) at the surface of the third, plasmic layer. The superficial coarse material is visible at the top, the right, and the bottom right corner of the photograph. (c) Site 2: Darker areas correspond to patches of microbiotic crust. Lighter parts are erosion crusts. (d) Site 3: Polygonal cracking of microbiotic crust on sedimentation crust, and rare herbaceous plants. (e) Site 4: Polygonal cracking of microbiotic crust on a sedimentation crust, showing the dense herbaceous cover, and soil reworked by termites (arrowed). Scale bar is $7.5 \mathrm{~cm}$. (f) Site 5: The soil is covered by a continuous litter layer. 

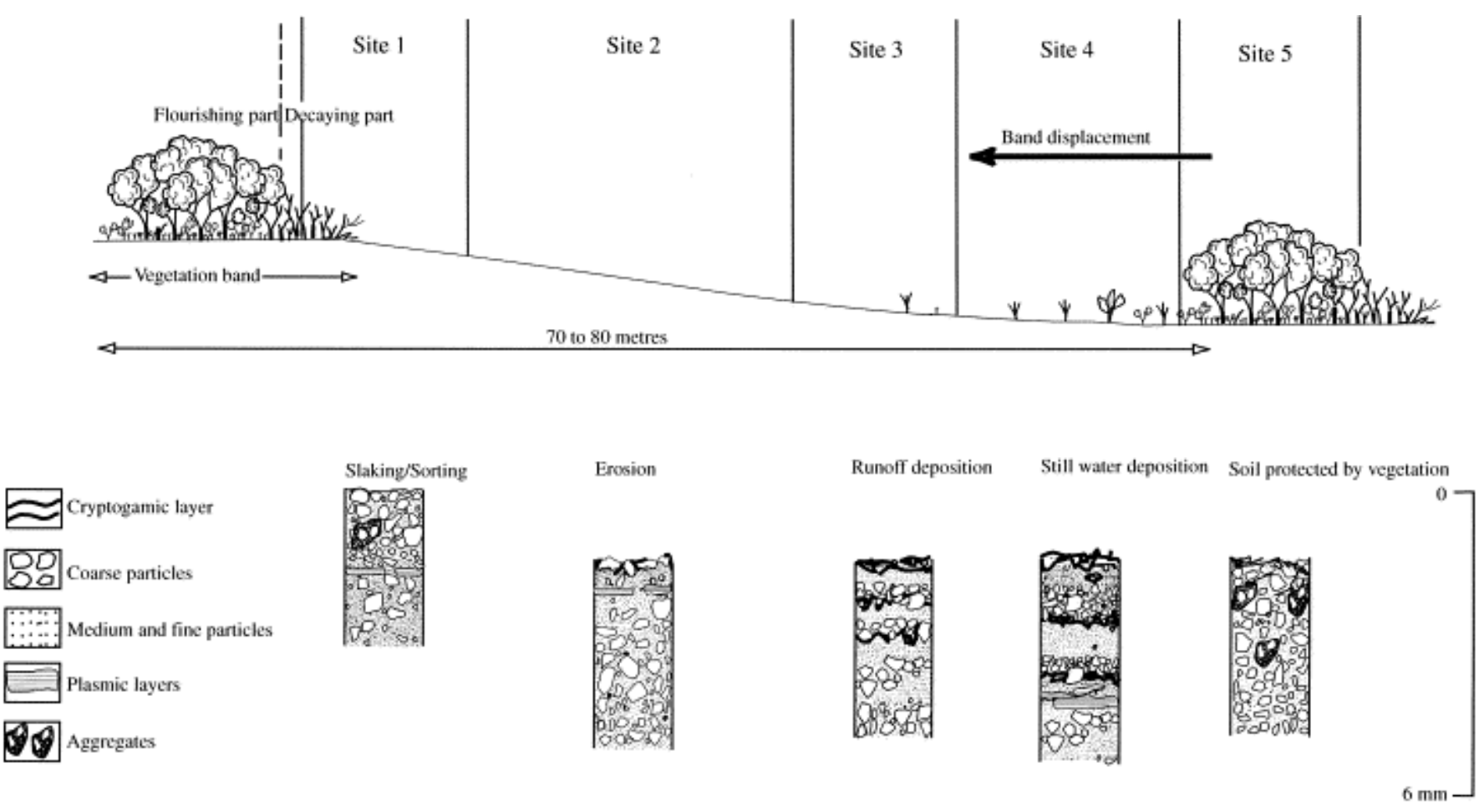

Fig. 3. Lateral and vertical patterns of a tiger bush soil sequence.

\subsection{Crust sampling}

Samples of soil crust approximately $7 \mathrm{~cm}$ thick were collected from each site (Fig. 3) in November 1994, at the beginning of the dry season. Five types of soil surface were distinguished along the slope, from the decaying part of a vegetative band to the flourishing part of the next lower vegetative band (Fig. 3).

(1) Site 1 (Fig. 2b): close to the decaying section of the band, the soil surface was a sieving crust devoid of any microbial cover. Vesicular pores formed as air bubbles were recognisable when unconsolidated coarse superficial material was swept out.

(2) Site 2 (Fig. 2c): the soil surface was an erosion crust partly capped by microbiotic crust patches.

(3) Site 3 (Fig. 2d): the soil surface was a microbiotic crust capping a still water deposition crust. Scattered herbaceous plants were present at this site.

(4) Site 4 (Fig. 2e): the soil surface was similar to that at site 3, but the grass vegetation was denser. Emerging holes of termite galleries were frequently observed.

(5) Site 5 (Fig. 2f): the soil surface under the flourishing part of the lower band was covered by a permanent litter of dead tree leaves and herbaceous plants. Scattered mosses were observed.

One sample was collected from each of the five sites. Those from sites 2 to 5 were divided into four subsamples for particle size distribution and chemical analyses. The first subsamples were the superficial organo-mineral layers, ca. $2 \mathrm{~mm}$ thick, which comprised most the living 
micro-organisms of the crusts. The other three subsamples were taken at 10-20 mm intervals according to visible soil layering.

\subsection{Methods}

Observations of soil surfaces were made at two scales, on a Nachet NS 50 stereomicroscope and on a JEOL JSM 6400 Scanning Electron Microscope (SEM). For SEM observations samples were coated with gold-palladium. Vertical thin sections were examined on a Zeiss Universal light microscope and on SEM. For SEM observations the sections were coated with carbon. Micro-organisms were collected from remoistened samples with a pipette under the stereomicroscope. Particle-size distributions were determined by dry sieving of sand particles and sedimentation of finer particles (pipette method). $\mathrm{pH}$ was measured with a $691 \mathrm{Metrohm}$ $\mathrm{pH}$ meter on samples dispersed in water for $24 \mathrm{~h}$. Total organic carbon (TOC) was measured with a CNS-2000 Leco analyser.

\section{Results}

\subsection{Physical and chemical analyses}

All sites had similar textures (sandy loam) and $\mathrm{pH}$ (4.7 to 6.5) values (Table 1). TOC content shows differences between sites, in particular in the superficial layers (Table 1). Superficial samples with a microbial cover (sites $2-4)$ were richer in TOC ( 0.9 to $1.9 \%$ dry weight) than the bare sample $(0.5 \%$ at site 1$)$. Densely microbially-covered samples (sites 3 and 4 ) were richer in TOC (1.8-1.9\%) than the litter-covered sample (1.4\% in site 5). Except for the sieving crust (site 1), the TOC content of deep samples was less than the superficial layers (Table 1). At depth, microbially-covered soils (sites $2-4)$ had less TOC $(0.3$ to $0.7 \%)$ than the litter-covered soil (site 5: 0.7\%) or the sieving crust (site 1: 0.6\%). Among microbiallycovered soils, site 4 , which supported a dense herbaceous cover, was richer in TOC $(0.4-$ $0.7 \%)$ at depth than sites 2 and $3(0.3-0.4 \%)$.

\subsection{Determination of micro-organisms}

Micro-organisms present in the tiger bush samples belonged to two taxonomical groups: cyanobacteria and chlorophyta (Table 2). Cyanobacteria were dominant at all sites, but Chlorophyta (two species) were present only in two sites. Eleven species of cyanobacteria were identified (Table 2). All are filamentous except C. limneticus. Three species are heterocystous. Schizothrix is the most abundant genus at all sites. The communities forming microbiotic crusts (sites 2-4) were not fundamentally different from those present in the vegetated band of the tiger bush (site 5 in Table 2). The maximum diversity of species was observed at site 3 . 
Table 1. Particle-size distribution, $\mathrm{pH}$ and total organic carbon content of the soils studied (values other than $\mathrm{pH}$ are dry weight percentages)

\begin{tabular}{|c|c|c|c|c|c|c|c|}
\hline \multirow[t]{2}{*}{ Sites } & \multirow[t]{2}{*}{ Physical crust type } & \multirow[t]{2}{*}{ Depth (mm) } & \multicolumn{3}{|c|}{ Particle size distribution } & \multirow[t]{2}{*}{$\mathrm{pH}$} & \multirow{2}{*}{$\begin{array}{l}\text { Total } \\
\text { organic } \\
\text { carbon }(\%)\end{array}$} \\
\hline & & & Sand (\%) & Silt $(\%)$ & Clay $(\%)$ & & \\
\hline \multirow[t]{2}{*}{ Site 1} & Sieving & $0-10$ & - & - & - & & 0.5 \\
\hline & & $10-15$ & 71.0 & 21.0 & 13.5 & 6.4 & 0.6 \\
\hline \multirow[t]{4}{*}{ Site 2} & Erosion & $0-2$ & 57.2 & 34.1 & 12.2 & 6.3 & 0.9 \\
\hline & & $2-35$ & 59.1 & 30.0 & 11.3 & 6.5 & 0.3 \\
\hline & & $35-55$ & 62.7 & 27.7 & 12.2 & 6.5 & 0.3 \\
\hline & & $55-75$ & 53.0 & 26.1 & 12.2 & 6.4 & 0.4 \\
\hline \multirow[t]{4}{*}{ Site 3} & Runoff deposition & $0-2$ & 54.2 & 29.4 & 13.8 & 5.9 & 1.8 \\
\hline & & $2-10$ & 64.3 & 20.3 & 10.7 & 5.4 & 0.4 \\
\hline & & $10-20$ & 64.5 & 24.8 & 10.0 & 5.0 & 0.3 \\
\hline & & $20-30$ & 64.0 & 18.4 & 14.1 & 5.0 & 0.3 \\
\hline \multirow[t]{4}{*}{ Site 4} & Still water deposition & $0-2$ & 70.4 & 24.0 & 4.9 & 6.1 & 1.9 \\
\hline & & $2-12$ & 59.5 & 34.3 & 7.2 & 5.8 & 0.7 \\
\hline & & $12-22$ & 51.6 & 32.8 & 13.3 & 6.1 & 0.5 \\
\hline & & $22-42$ & 54.9 & 31.8 & 13.4 & 6.1 & 0.4 \\
\hline \multirow[t]{4}{*}{ Site 5} & No crust & $0-2$ & 60.5 & 37.4 & 3.8 & 5.8 & 1.4 \\
\hline & & $2-17$ & 64.6 & 20.6 & 11.5 & 5.5 & 0.7 \\
\hline & & $17-37$ & 70.2 & 18.9 & 13.1 & 4.7 & 0.7 \\
\hline & & $37-57$ & 72.6 & 17.5 & 13.5 & 5.5 & 0.7 \\
\hline
\end{tabular}

Table 2. Micro-organisms observed in the sites studied (no micro-organism was observed at site 1)

\begin{tabular}{|c|c|c|c|c|c|}
\hline & Taxons & $\begin{array}{l}\text { Site } 2 \text { : } \\
\text { erosion crust }\end{array}$ & $\begin{array}{l}\text { Site 3: } \\
\text { runoff } \\
\text { deposition crust }\end{array}$ & $\begin{array}{l}\text { Site } 4 \text { : } \\
\text { still water } \\
\text { deposition crust }\end{array}$ & $\begin{array}{l}\text { Site } 5 \text { : } \\
\text { no crust }\end{array}$ \\
\hline \multirow[t]{11}{*}{ Cyanobacteria } & Chroococcus limneticus Lemm. & + & - & - & - \\
\hline & $\begin{array}{l}\text { Lyngbya aerugineo-coenulea } \\
\text { (Kütz.) Gomont }\end{array}$ & - & - & + & - \\
\hline & L. aestuarii Liebman & - & - & - & + \\
\hline & L. epiphytica Hieron & - & - & - & + \\
\hline & $\begin{array}{l}\text { Microcoleus sociatus } \\
\text { W and G.S. West }\end{array}$ & - & + & - & + \\
\hline & *Nostoc Vaucher sp. & - & + & - & - \\
\hline & Phormidium mucosum Gardner & - & + & - & - \\
\hline & Schizothrix friesii (Ag.) Gomont & + & + & + & + \\
\hline & S. penicillata (Kütz.) Gomont & + & + & + & - \\
\hline & * Scytonema javanicum Bornet & - & + & - & - \\
\hline & * Scy. stuposum (Kütz) Bornet & - & + & - & - \\
\hline \multirow[t]{2}{*}{ Chlorophyta } & $\begin{array}{l}\text { Desmococcus olivaceus } \\
\text { (Pers. ex Arch.) Laundon }\end{array}$ & + & - & - & - \\
\hline & $\begin{array}{l}\text { Actinotaenium cucurbita fo. } \\
\text { rotundatum (Krieg.) Teiling }\end{array}$ & - & - & - & + \\
\hline
\end{tabular}

$+=$ Presence

* $=$ Heterocystous species. 


\subsection{Surface micromorphology}

\subsubsection{Site 1}

Microscopic observations confirmed the absence of micro-organisms at this site. The material is composed essentially of rounded quartz grains, ca. $500 \mu \mathrm{m}$ in mean diameter, accompanied by rare coarser sand grains (Fig. 4a). Pores probably resulting from insect activity were observed (Fig. 4a).
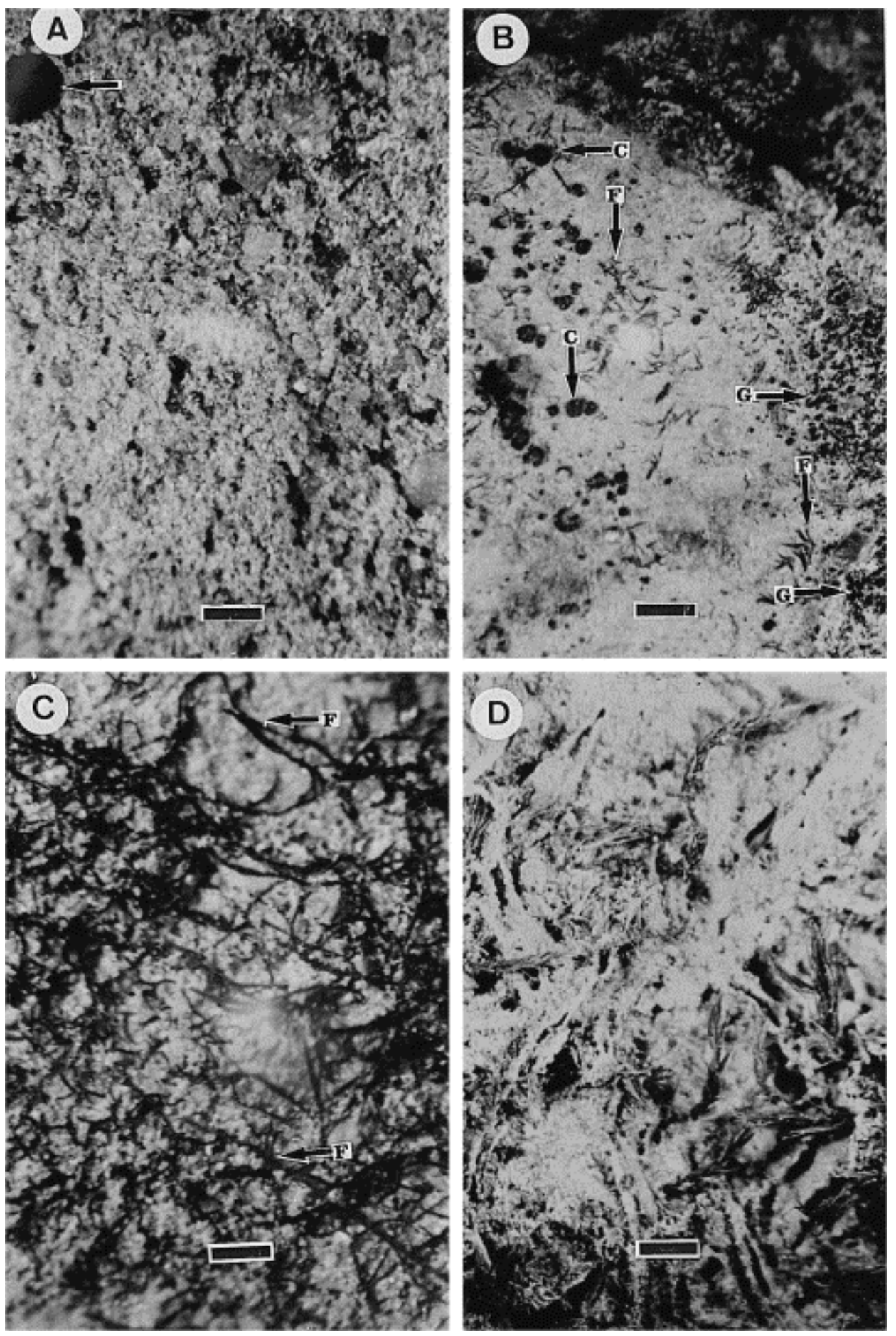

Fig. 4. Views of the soil surface under a stereomicroscope. (a) Site 1: Note the absence of any living organism or organic material, and the pore probably resulting from insect activity (arrowed) (scale bar is $0.5 \mathrm{~mm}$ ). (b) Site 2: 
Small globular colonies of cyanobacteria (C. limneticus Näg.; G), larger, cupular chlorophyta (Desmococcus Brand; C), and filamentous cyanobacteria (Schizothrix Kütz.; F) (scale bar is $0.5 \mathrm{~mm}$ ). (c) Site 4: Note the network of cyanobacterial filaments (F) (scale bar is $0.1 \mathrm{~mm}$ ). (d) Site 5: Mosses on the surface of litter. Scale bar is $0.5 \mathrm{~mm}$.

\subsubsection{Site 2}

Stereomicroscopic observations of microbiotic crust patches revealed the presence of three different microbial colonies.

(1) Black, globular organisms, approximately $10 \mu \mathrm{m}$ in diameter when isolated, and $250 \mu \mathrm{m}$ when associated (Fig. 4b). These were identified as cyanobacteria of the species C. limneticus (Table 2).

(2) Black or reddish, filamentous organisms, 10 to $25 \mu \mathrm{m}$ in diameter (Fig. $4 \mathrm{~b}$ ), belonging to two species of the cyanobacterial genus Schizothrix (Table 2).

(3) Greenish, cupular-shaped organisms, 250 to $400 \mu \mathrm{m}$ in diameter (Fig. 4b), identified as chlorophyta belonging to the genus Desmococcus (Table 2).

Under SEM the Schizothrix filaments appeared to form a superficial network delineating pores, several tens of micrometres in diameter (Fig. 5a). Sand particles were trapped in this network, whereas finer mineral particles adhered to the surface of filaments (Fig. 5a).
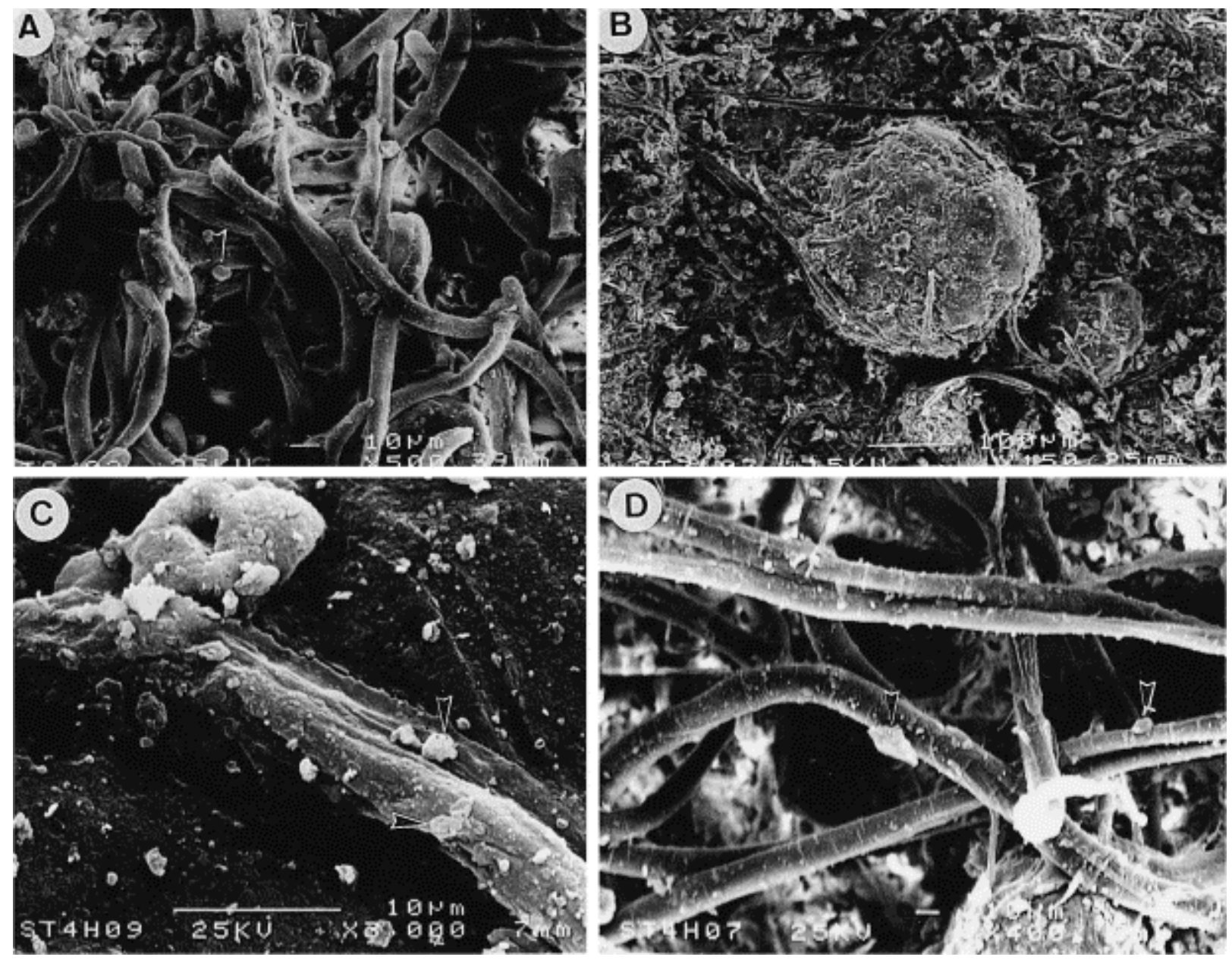
Fig. 5. SEM micrographs of the soil surface. (a) Site 2: Intertwining of filaments, which trap sand grains. Fine mineral particles stick onto the surfaces of filaments (arrowed). (b) Site 3: Network of filaments enmeshing sand grains and finer mineral particles. (c) Site 4: Contact between a filament and a sand grain. Note the filament print on the grain surface. Fine particles (arrowed) adhere to the filament surface. (d) Site 4: Filaments delineating superficial pores. Fine mineral particles adhere to the surfaces of filaments (arrowed). Bar is $10 \mu \mathrm{m}$.

\subsubsection{Sites 3 and 4}

Under the stereomicroscope there was no significant micromorphological difference between sites 3 and 4, except that the density of micro-organisms was greater at site 4 . The surface of crusts appeared to be formed by a network of black or reddish filaments, 10 to $25 \mu \mathrm{m}$ in diameter (Fig. 4c). Some filaments formed pinnacles rising above the flat surface of the crust. Under SEM the filaments appeared, as at site 2, to trap sand particles and to have finer $(<5$ $\mu \mathrm{m})$ mineral particles adhering (Fig. 5b-c). The filaments delineated characteristic superficial pores, several tens of micrometres in diameter (Fig. 5d). Filament prints were observed on the surface of sand grains (Fig. 5c). Scattered liverworts were present at site 4.

\subsubsection{Site 5}

At the stereomicroscope scale, the soil surface appeared to be covered by debris of higher plants, mainly tree leaves. Mosses were especially abundant (Fig. 4d) and liverworts were also present. Rare very thin, colourless filamentous micro to organisms were observed in association with rare globular micro-organisms, $100-150 \mu \mathrm{m}$ in diameter. SEM observations indicated the presence of two species of diatoms.

\subsection{Vertical cross-section observations}

\subsubsection{Site 1}

Two different layers were distinguished at this site (Fig. 6a): a superficial layer, 0.5-1.5 mm thick, which contained sand with rare disrupted soil aggregates, and an underlying layer, $>4$ $\mathrm{cm}$ thick, which contained consolidated clay-rich material with rare sand grains. The porosities of the two layers were different (Fig. 6a): pores in the top layer were partially clogged by plasmic material, but in the underlying layer they exhibited laminated clay coatings, probably resulting from illuviation. The two layers correspond, respectively, to the medium layer of fine sand and the bottom layer of fine particles of a sieving crust (Fig. 1). 

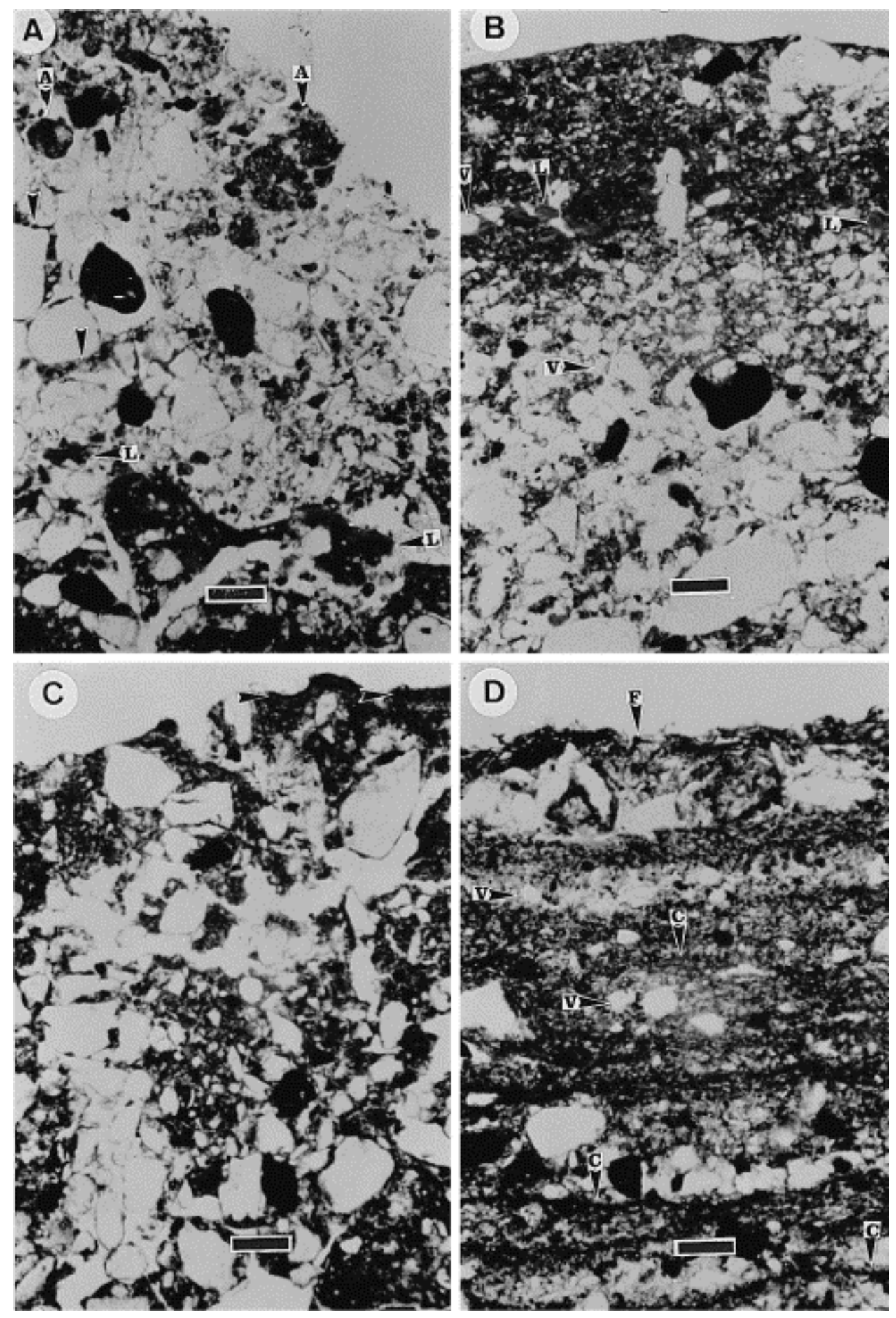

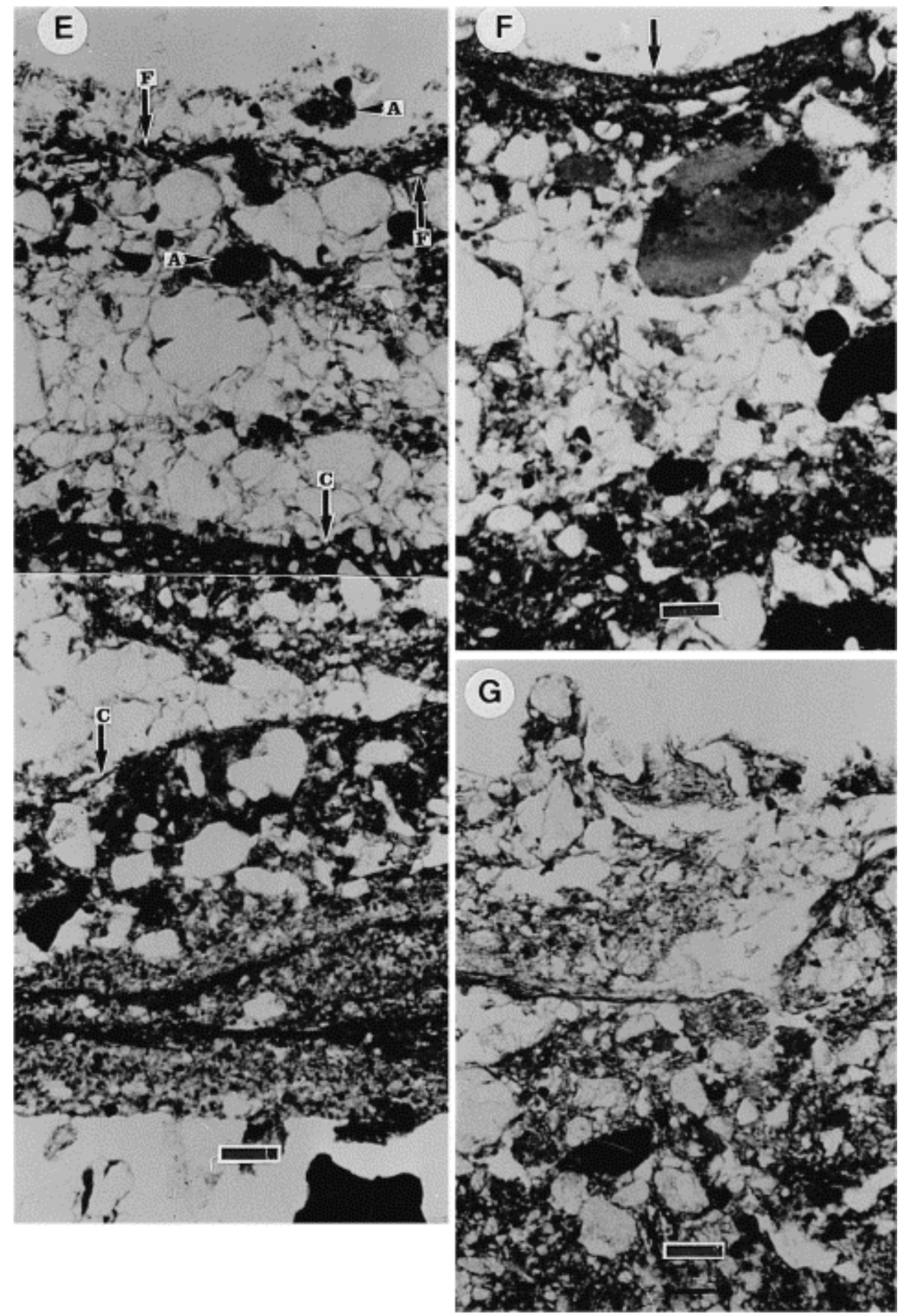

Fig. 6. Photomicrographs of vertical thin sections of soils. Scale bars are $160 \mu \mathrm{m}$. (a) Site 1: Sieving crust. Superficial layer of fine sand with disrupted aggregates (A) and clogged pores (arrowed), on a clay rich layer with laminated void coatings (L). The soil surface (upper right) is devoid of organisms. (b) Site 2: Erosion crust. The superficial plasmic layer exhibits laminated clay coatings (L) and rounded to vesicular pores (V). The underlying layer is formed by mixed material and exhibits polyconcave pores (V). (c) Site 2: Area covered with a discontinuous layer of living organisms (arrowed). The plasmic layer is thinner than in bare areas of the same site (b). (d) Site 3: Runoff deposition crust capped by a continuous superficial layer of living filamentous microorganisms (F). The profile shows alternation of submillimetric sand and clay layers, and non-connected vesicular pores (V). Ancient microbiotic crusts (C) can be recognised at depth. (e) Site 4: Still water deposition crust capped by a continuous layer of living filamentous micro-organisms (F). The profile shows alternating clay and sand layers, which are thicker and better sorted than at site 3. Superficial layers include disrupted aggregates (A). Ancient microbiotic crusts (C) are seen at depth. (f) Site 4: Polygonal cracking (arrowed) of the superficial microbiotic crust. (g) Site 5: Superficial litter layer on non-layered mixed soil material. 


\subsubsection{Site 2}

In the areas devoid of microbial cover, two layers were distinguished (Fig. 6b): a superficial layer, $0.8-1.5 \mathrm{~mm}$ thick, formed from plasmic material with rare sand grains, and an underlying layer, several centimetres thick, formed from mixed material. The plasmic layer was smooth and rigid and resulted from clay illuviation, as indicated by the abundance of laminated coatings (Fig. 6b). Pores were rounded to vesicular because of compaction, and partially clogged by clay washed from the soil surface. These features are characteristic of erosion crusts (Fig. 1). The lower layer contained mixed, non-sorted material, which consisted mostly of mixed sand, clay in intergrain spaces and non-living organic material (Fig. 6b).

In the areas covered with a microbiotic crust (Fig. 6c), the plasmic layer was thinner $(0.1-0.2$ $\mathrm{mm}$ thick), more structured, and contained more sand grains and non-living organic material than in bare areas (Fig. 6b). The boundary with the underlying layer of mixed material was diffuse. Pores were tubular and interconnected. Under SEM, the organic constituents of this layer, in particular the filaments, appeared to surround and bind soil particles into a coherent network (Fig. 7a,b). Organic bodies with a porous structure and comprising micron-sized spheres were frequently observed (Fig. 7a,c). X-ray microanalysis of the organic constituents revealed detectable amounts of $\mathrm{Cl}, \mathrm{K}$ and $\mathrm{Na}$, in addition to $\mathrm{C}$.
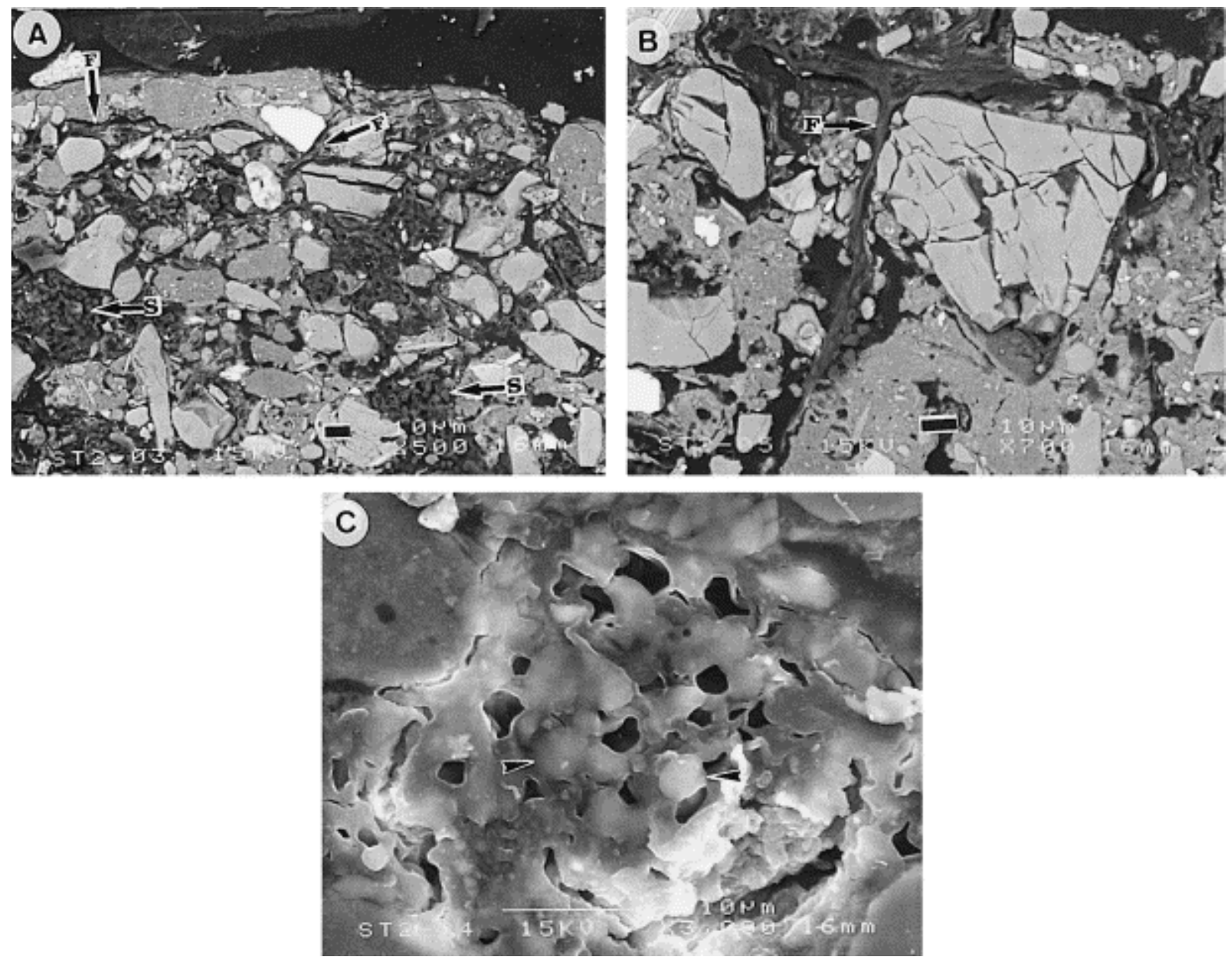

Fig. 7. SEM micrographs (backscattered electron mode) of a vertical thin section at site 2. (a) Cyanobacterial filaments (F) and dark organic bodies enmesh mineral grains. Some organic bodies appear to be micron-sized 
spheres (S). (b) Enlarged view of an area in (a), showing cyanobacterial filaments (F) surrounding mineral grains. (c) Enlarged view of a dark organic body in (a). Note the porous structure of the organic matter and the presence of microspheres (arrowed).

\subsubsection{Site 3}

The soil profile exhibited alternating clay- and sand-rich layers (Fig. 6d) characteristic of runoff deposition crusts (Fig. 1). The soil can be subdivided into rhythmic units of variable thickness (0.2-0.4 mm), composed of a layer of sand overlying a thin layer of clay (Fig. 6d). Pores were rounded to vesicular because of compaction (Fig. 6d). The superficial microbiotic crust comprising filamentous cyanobacteria was formed at the surface of a clay layer (Fig. $6 \mathrm{~d})$. Ancient microbiotic crusts were recognised at depth as black organic laminae overlying clay layers (Fig. 6d). Filaments and porous organic bodies similar to those at site 2 (Fig. 7a,c) were also observed by SEM in this site, below the superficial layer of living cyanobacteria. Xray microanalysis again indicated detectable amounts of $\mathrm{Cl}, \mathrm{K}$ and $\mathrm{Na}$ in the organic material.

\subsubsection{Site 4}

As at site 3, the soil exhibited alternating layers of clay and sand (Fig. 6e). The microbiotic crust, $0.7 \mathrm{~mm}$ thick and made of filamentous cyanobacteria, was formed at the surface of a clay layer ca. $0.1 \mathrm{~mm}$ thick (Fig. 6e). Superficial polygonal cracking was observed with the light microscope (Fig. 6f). Filaments and porous organic bodies, similar to those present at sites 2 (Fig. 7a,c) and 3, were observed at depth, also with the same enrichment in $\mathrm{Cl}, \mathrm{K}$ and $\mathrm{Na}$.

Below the microbiotic crust, the soil profile was composed of two successive units (Fig. 6e): in the upper unit ca. $3 \mathrm{~mm}$ thick, the clay and sand layers were thicker $(0.6-1 \mathrm{~mm})$ and better sorted than at site 3, whereas the microstructure of the lower unit was closer to that at site 3 . In the clay layers of the upper unit the clay was usually associated with non-living organic matter at the top, but was mixed with silt and sand particles at the bottom (Fig. 6e). The features of the upper unit are characteristic of a still water deposition crust. As at site 3, ancient microbiotic crusts were recognised at depth (Fig. 6e).

\subsubsection{Site 5}

Two different layers were distinguished at this site (Fig. 6g): a superficial, discontinuous layer, ca. $1 \mathrm{~mm}$ thick consisting of mixed higher plant debris, sand grains, and finer mineral particles and an underlying layer consisting of material of various sizes disturbed by vegetation growth.

\section{Discussion}

\subsection{Biological composition}

As observed by others, the microbiotic crusts we studied were formed by microbial communities dominated by cyanobacteria. However, they differed from most other crusts in that the prevalent genus was Schizothrix (Table 2). Other microbiotic crusts are dominated by Scytonema sp. in the N'Djamena region, Tchad (Dulieu et al., 1977) and in savanna zones of Nigeria (Isichei, 1980), by M. sociatus in the western Negev Desert, Israel (Lange et al., 1992) and by Microcoleus spp. in desert soil crusts in Idaho, Utah and Colorado (Brock, 
1975; Campbell, 1979). In semi-arid and arid lands of North America, the most widespread species of cyanobacteria is $M$. vaginatus. (Vauch.) Gom. Only in hot desert regions have microbiotic crusts been hitherto reported to consist mainly of Schizothrix (Johansen, 1993). Chlorophyta and liverworts are also common components of the microbiotic crusts in the tiger bush.

\subsection{Soil stabilisation}

Micro-organisms and mineral grains are closely associated at the surface of the tiger bush microbiotic crusts. The network of filamentous cyanobacteria traps sand grains, and clay and silt sized particles adhere to the surfaces of filaments (Fig. 4cFig. 5a,b,d). This has already been noted in other microbiotic crusts by Cameron and Devaney (1970) and Belnap and Gardner (1993). The ability of cyanobacterial filaments to cement mineral particles to the surface of their polysaccharide envelopes is well known (Pentecost and Riding, 1986). Filament prints on the surface of mineral grains (Fig. 5c) suggest slight dissolution of the mineral at the contact with the filament.

Below the superficial layer of living cyanobacteria intermingled with mineral grains, filaments and organic bodies also appear to enmesh soil mineral particles (Fig. 6d,eFig. 7a,b). The porous organic bodies presumably derive from extracellular polymer secretions (EPS) of micro-organisms. Cyanobacteria and other bacteria commonly produce polysaccharide EPS which reorganize into three-dimensional networks (Défarge et al., 1996). The role of EPS in soil aggregate stabilisation has already been mentioned by Tisdall and Oades (1982). In the tiger bush soils this organic matter could be produced by the filamentous cyanobacteria or the microspheres (bacteria?) associated with the porous bodies (Fig. 7a,c).

The micro-organisms which form tiger bush microbiotic crusts thus provide cohesion to the soil through the trapping and binding effects of superficial living filaments and of microbial organic material present at depth. This cohesion enhances soil stabilisation against water and wind erosion, as was confirmed by placing bare soil samples from site 1 in water; they were completely dispersed after two days, whereas microbiotic crust samples from sites 2 to 4 remained intact after several months of immersion. In situ measurements made at other sites near Banizoumbou have shown that fewer mineral particles are removed from microbiallycovered soils compared with bare soils (Malam Issa et al., 1998). These results agree with other studies, which have shown less erosion of soils covered by microbiotic crusts (Eldridge and Greene, 1994; McKenna Neuman et al., 1996; Eldridge and Kinnell, 1997).

At sites 3 and 4, the depositional crusts were interlayered at depth with ancient microbiotic crusts (Fig. 6d,e). In addition to their role in stabilisation of underlying soil, microbiotic crusts are thus probably involved in mineral particle retention and deposition on their surface, and therefore in soil accretion. Cyanobacterial mats, including Schizothrix-dominated mats, have been shown to control underwater particle sedimentation in shallow subtidal and intertidal marine areas (Neumann et al., 1970). In the depositional sites of the tiger bush, soil accretion occurs through a rhythmic aggradation of layers, alternately organic and mineral. The resulting structure is sedimentary rather than pedogenetic, and may be considered as a terrestrial stromatolite. Similarities between certain microbiotic soil crusts and stromatolites were noted by Campbell (1979). 


\subsection{Soil-water interactions}

Microscopic observations of tiger bush samples revealed two features which may influence the water regime of the soil: (1) intertwining of the filamentous organisms at the soil surface delineates pores of significant sizes (Fig. 5a,d), which could favour water infiltration; (2) the presence of porous organic bodies at depth (Fig. 7a,c), which enhances the water retention capacity of the soil.

When wetted, two possible kinds of behaviour can be expected from the polysaccharide constituents of cyanobacterial envelopes and of spongy organic bodies: (1) swelling resulting from absorption of water by the polysaccharide constituents is limited and the pore field allows water circulation, or (2) swelling reduces the pore size and enhances water retention by capillary forces. According to Verrecchia et al. (1995), the absorption of water by biological material and the retention of water by strong capillary forces are the ways in which microbiotic crusts limit water infiltration and promote runoff when rain starts.

The influence on the water regime of other organisms such as termites, which were conspicuous at site 4 (Fig. 2e), should also be considered. The foraging activity of these organisms has been shown to enhance water infiltration (Ouedraogo, 1997).

Further studies are necessary to determine the interactions of tiger bush microbiotic crusts and water. Laboratory measurements have indicated that microbial crusts enhance the water retention capacity of Sahelian soils similar to those of the tiger bush. At $\mathrm{pF} 2.5$, water retention was $6.8-36 \%$ for microbially-covered samples but only $2.1-3.8 \%$ for bare samples (Malam Issa, unpubl. data).

\subsection{Chemical composition}

The presence of photosynthetic micro-organisms may account for the organic $\mathrm{C}$ enrichment of the surface layer of microbiotic crusts compared with bare and litter-covered soils (Table 1). The phototrophs fix atmospheric $\mathrm{CO}_{2}$ at rates estimated by Beymer and Klopatek (1991) for microbiotic crusts in Pinyon-Juniper woodlands (Northern Arizona, USA) to range from 43 (grazed soil) to $350 \mathrm{~kg} \mathrm{C} \mathrm{ha}^{-1} \mathrm{yr}^{-1}$ (ungrazed soil). A sample from site 4 of Banizoumbou tiger bush has been shown to fix $4.3-5.3 \mathrm{mg} \mathrm{C} \mathrm{m}^{-2} \mathrm{mn}^{-1}$ under laboratory conditions (Malam Issa, unpubl. data).

The supply of nitrogen in microbiotic crusts is mainly from cyanobacteria and lichens (Mayland et al., 1966; Jeffries et al., 1992). Nitrogen fixation in crusts can vary from 1 to 100 $\mathrm{kg} \mathrm{N}_{2} \mathrm{ha}^{-1} \mathrm{yr}^{-1}$ (Jeffries et al., 1992). In the tiger bush soils, which do not support lichens, nitrogen should be fixed mainly by the heterocystous cyanobacterial species Nostoc sp., Scy. javanicum and Scy. stuposum (Table 2). Some other species of cyanobacteria devoid of heterocysts are also able to fix nitrogen (Stal, 1995; Bergman et al., 1997).

\subsection{Microbiotic crusts in tiger bush dynamics}

The microscopic features of the tiger bush sequence revealed a specific organization of the soil between successive vegetated bands (Fig. 3). From the decaying part of the upper band down to the flourishing part of the lower band, the soil surface consists successively of a sieving crust (site 1), an erosion crust (site 2), a runoff sedimentation crust (site 3 ) and a still water deposition crust (site 4 ). In site 4 , the still water deposition crust caps an ancient runoff 
deposition crust analogous to that at site 3 (Fig. 3). The superficial layer of the crust at site 2 corresponds to the lower, plasmic layer of the sieving crust at site 1 (compare Fig. 6a and b). The erosion crust at site 2 probably results from the evolution of a sieving crust (Fig. 3). Deposition of particles translocated from sites 1 and 2 induces the formation of depositional crusts at sites 3 and 4 (Fig. 3). These observations confirm the dynamic model of Bresson and Valentin (1990). The downward movement of water which controls the formation of the tiger bush landscape is also responsible for the organisation of soil between the vegetated bands.

The cyclic evolution which results from the upslope migration of vegetated bands also affects the soil crusts. Vegetation decay at site 5 creates a bare soil which will evolve into a structural crust (site 1 type). The structural crust will be replaced by an erosion crust (site 2 type), then by a depositional crust (site 3 and site 4 types) supplied by particles translocated from structural and erosion crusts formed above. The depositional crust will be progressively invaded by the upslope migrating vegetation and thus become a site 5 type soil.

The microbiotic crusts are essential components of the tiger bush ecosystem. The zonation of microbiotic crusts is parallel to the tiger bush banding (Fig. 3). Site 1 is devoid of any microbial cover. The density of microbial cover increases from site 2 to site 4 , and the microbial communities present at site 5 are close to those forming microbiotic crusts at sites 2 to 4 (Table 2). The most extensive development of microbiotic crusts is associated with temporary accumulations of water at site 4 . The microbial cover enhances stabilisation of depositional crusts and promotes retention of sand and clay particles on their surface. The continuous aggradation of mineral layers, whose surface is recolonised by micro-organisms after deposition, results in soil accretion at this site. The resulting soil provides a stabilised, well-moistened and nutrient-enriched substrate for the upslope migration of plants from the adjacent vegetated band (site 5). The microbiotic crusts are then destroyed by root and faunal bioturbation which follows the establishment of higher plants.

\section{Conclusions}

This study has documented further occurrences of microbiotic crusts formed by cyanobacteria, chlorophyta and liverworts on the surface of soils in semi-arid tiger bush woodlands. The results confirm the role of a microbial cover and derived organic matter in microstructure development and stabilisation of the soils.

The microbiotic crusts are essential components of the tiger bush ecosystem. The downward movement of water, which controls the dynamics of the tiger bush landscape, also controls the lateral and vertical successions of crusts in the tiger bush sequence studied. The formation of microbiotic crusts in the lower parts of bare bands helps retain water, resist erosion and accumulate soil. Microbial activity also results in $\mathrm{C}$ and $\mathrm{N}$ enrichment of superficial soil. The upslope development of trees and shrubs of the vegetated bands takes place on this substrate. The development of microbiotic crusts between the zones with higher plants appears to be a biological adaptation favourable to the preservation of the structure and nutrient level of the soil during periods of denudation.

Microbiotic crusts may thus play a specific role in the conservation and improvement of soil properties in Sahelian regions. Through increase of resistance to erosion, enrichment in essential nutrients, and control on water uptake, they can favour the establishment of farm crops. 


\section{Acknowledgements}

This project was supported by ORSTOM and the paper is a contribution to the IGCP Project 380 'Biosedimentology of microbial buildups'. J.L. Rajot helped with field work. Thin sections were made in the Institut National Agronomique de Paris-Grignon by L.M. Bresson. A. Genty and C. Lelay helped with microscopic observations, and B. Guillet with particle size analyses. Reviews by D.J. Eldridge and A. Yair significantly improved the paper.

\section{References}

Ambouta, K., 1984. Contribution à l'édaphologie de la brousse tigrée de l'Ouest nigérien. Thèse de Docteur-Ingénieur, Université Nancy I, France, 116 pp.

Ambouta, J.M.K., 1997. Définition et caractérisation des structures de végétation contractée au Sahel: cas de la brousse tigrée de l'ouest nigérien. In: d'Herbès, J.M., Ambouta, J.M.K., Peltier, R. (Eds.), Fonctionnement et Gestion des Écosystèmes Forestiers Contractés Sahéliens. John Libbey Eurotext, Paris, pp. 41-57.

Barbey, C., Couté, A., 1976. Croûtes à cyanophycées sur les dunes du Sahel mauritanien. Bulletin de l'I.F.A.N. 38, sér. A, 732-736.

Belnap, J. and Gardner, J.S., 1993. Soil microstructure in soils of the Colorado Plateau: the role of the cyanobacterium Microcoleus vaginatus. Great Basin Naturalist 53, pp. 40-47

Bergman, B., Gallon, J.R., Rai, A.N. and Stal, L.J., 1997. $\mathrm{N}_{2}$ fixation by non-heterocystous cyanobacteria. FEMS Microbiol. Rev. 19, pp. 139-185

Beymer, R.J. and Klopatek, J.M., 1991. Potential contribution of carbon by microphytic crusts in Pinyon-Juniper woodlands. Arid Soil Res. Rehab. 5, pp. 187-198

Bresson, L.M., Valentin, C., 1990. Comparative micromorphological study of soil crusting in temperate and arid environments. Trans. 14th Int. Congr. Soil Sci., Kyoto, Japan, VII, pp. $238-243$.

Brock, T.D., 1975. Effect of water potential on a Microcoleus (Cyanophyceae) from a desert crust. J. Phycol. 11, pp. 316-320

Brotherson, J.D. and Rushforth, S.R., 1983. Influence of cryptogamic crusts on moisture relationships of soils in Navajo National Monument, Arizona. Great Basin Naturalist 43, pp. $73-78$

Cameron, R.E. and Devaney, J.R., 1970. Antarctic soil algal crusts: scanning electron and optical microscope study. Trans. Am. Microsc. Soc. 89, pp. 264-273

Campbell, S.E., 1979. Soil stabilisation by a prokaryotic desert crust: implications for Precambrian land biota. Origins of Life 9, pp. 335-348 
Campbell, S.E., Seeler, J.S. and Golubic, S., 1989. Desert crust formation and soil stabilisation. Arid Soil Res. Rehab. 3, pp. 217-228

Cole, D.N., 1990. Trampling disturbance and recovery of cryptogamic soil crusts in Grand Canyon National Park. Great Basin Naturalist 50, pp. 321-325

Cornet, A.F., Montana, C., Delhoume, J.P., Lopez-Portillo, J., 1992. Water flows and the dynamics of desert vegetation stripes. In: Hansen, A.J., Di Castri, F. (Eds.), Landscape Boundaries. Consequences for Biotic Diversity and Ecological Flows. Springer-Verlag, New York, pp. 327-345.

d'Herbès, J.M., Valentin, C., Thiéry, J.M., 1997. Synthèse des connaissances acquises sur la brousse tigrée nigérienne: hypothèse sur la genèse et les facteurs déterminant les différentes structures contractées. In: d'Herbès, J.M., Ambouta, J.M.K., Peltier, R. (Eds.), Fonctionnement et Gestion des Écosystèmes Forestiers Contractés Sahéliens. John Libbey Eurotext, Paris, pp. 131-152.

Défarge, C., Trichet, J., Jaunet, A.M., Robert, M., Tribble, J. and Sansone, F.J., 1996. Texture of microbial sediments revealed by cryo-scanning electron microscopy. J. Sedimentary Res. 66, pp. 935-947

Dulieu, D., Gaston, A. and Darley, J., 1977. La dégradation des pâturages de la région de N'Djamena (Rép. du Tchad) en relation avec la présence de cyanophycées psammophiles: étude préliminaire. Revue d'Elevage et de Médécine Vétérinaire des Pays Tropicaux 30, pp. $181-190$

Eldridge, D.J., 1993. Cryptogams, vascular plants, and soil hydrological relations: some preliminary results from the semiarid woodlands of eastern Australia. Great Basin Naturalist 53, pp. 48-58

Eldridge, D.J., 1993. Cryptogam cover and soil surface condition: effects on hydrology on a semiarid woodland soil. Arid Soil Res. Rehab. 7, pp. 207-217

Eldridge, D.J. and Greene, R.S.B., 1994. Assessment of sediment yield by splash erosion on a semi-arid soil with varying cryptogam cover. J. Arid Environ. 26, pp. 221-232

Eldridge, D.J. and Kinnell, P.I.A., 1997. Assessment of erosion rates from microphytedominated calcareous soils under rain-impacted flow. Aust. J. Soil Res. 35, pp. 475-489

Greigert, J., 1966. Description des formations crétacés et tertiaires du bassin des Iullemmeden (Afrique occidentale). Publications de la Direction Mines et Géologie, Niger, 2. Bureau de Recherches Géologiques et Minières, Niamey, Niger, 234 pp.

Harper, K.T. and Pendleton, R., 1993. Cyanobacteria and cyanolichens: can they enhance availability of essential minerals for higher plants?. Great Basin Naturalist 53, pp. 59-72

Isichei, A.O., 1980. Nitrogen fixation by blue-green algal soil crusts in Nigerian savannah. In: Rosswall, T. (Ed.), Nitrogen Cycling in West African Ecosystems. SCOPE-UNEP International Nitrogen Unit, Royal Swedish Academy of Sciences, Stockholm, pp. 191-198. 
Jeffries, D.L., Klopatek, J.M., Link, S.O. and Bolton Jr., H., 1992. Acetylene reduction by cryptogamic crusts from a blackbrush community as related to resaturation and dehydration. Soil Biol. Biochem. 24, pp. 1101-1105

Johansen, J.R., 1993. Cryptogamic crusts of semiarid and arid lands of North America. J. Phycol. 29, pp. 140-147

Klubek, B. and Skujins, J., 1980. Heterotrophic $\mathrm{N}_{2}$-fixation in arid soil crusts. Soil Biol. Biochem. 12, pp. 229-236

Lange, O.L., Kidron, G.J., Büdel, B., Meyer, A., Kilian, E. and Abeliovich, A., 1992. Taxonomic composition and photosynthetic characteristics of the 'biological soil crusts' covering sand dunes in the western Negev Desert. Functional Ecology 6, pp. 519-527

Loope, W.L. and Gifford, G.F., 1972. Influence of a soil microfloral crust on select properties of soils under Pinyon-Juniper in southeastern Utah. J. Soil Water Conserv. 27, pp. 164-167

Malam Issa, O., Trichet, J., Défarge, C., Valentin, C., Rajot, J.L., 1998. Micromorphology of microbiotic crusts from Niger soils. Influence on soil-water dynamics. Trans. 16th Int. Congr. Soil Sci., Montpellier, France, Symp. 30, 961, 7 pp.

Mayland, H.F., McIntosh, H.T. and Fuller, W.H., 1966. Fixation of isotopic nitrogen on a semiarid soil by algal crust organisms. Soil Sci. Soc. Am. Proc. 30, pp. 56-60

McKenna Neuman, C.M., Maxwell, C. and Boulton, J.W., 1996. Wind transport of sand surfaces crusted with photoautotrophic microorganisms. Catena 27, pp. 229-247

Neumann, A.C., Gebelein, C.D. and Scoffin, T.P., 1970. The composition, structure and erodability of subtidal mats, Abaco, Bahamas. J. Sedimentary Petrol. 40, pp. 274-297

Ouedraogo, P., 1997. Rôle des termites dans la structure et la dynamique d'une brousse tigrée soudano-sahélienne. Thèse de doctorat, Université Paris VI, France, 282 pp.

Pentecost, A., Riding, R., 1986. Calcification in cyanobacteria. In: Leadbeater, B.S.C., Riding, R. (Eds.), Biomineralization in Lower Plants and Animals. Clarendon Press, Oxford, pp. 73-90.

Reynaud, P.A. and Lumpkin, T.A., 1988. Microalgae of the Lanzhou (China) cryptogamic crust. Arid Soil Res. Rehab. 2, pp. 145-155

Rychert, R.C. and Skujins, J., 1974. Nitrogen fixation by blue-green algae-lichen crusts in the Great Basin Desert. Soil Sci. Soc. Am. Proc. 38, pp. 768-771

Stal, L.J., 1995. Physiological ecology of cyanobacteria in microbial mats and other communities. New Phytol. 131, pp. 1-32

Thiéry, J.M., d'Herbès, J.M. and Valentin, C., 1995. A model simulating the genesis of banded patterns in Niger. J. Ecology 83, pp. 497-507 
Tisdall, J.M. and Oades, J.M., 1982. Organic matter and water-stable aggregates in soils. $J$. Soil Sci. 33, pp. 141-163

Verrecchia, E., Yair, A., Kidron, G.J. and Verrecchia, K., 1995. Physical properties of the psammophile cryptogamic crust and their consequences of the water regime of sandy soils, North-western Negev Desert, Israel. J. Arid Environ. 29, pp. 427-437 